\title{
Applying reflection and moderation in an asynchronous computer-supported collaborative learning environment in campus-based higher education.
}

Citation for published version (APA):

Dewiyanti, S., Brand-Gruwel, S., \& Jochems, W. M. G. (2005). Applying reflection and moderation in an asynchronous computer-supported collaborative learning environment in campus-based higher education. British Journal of Educational Technology, 36(4), 673-676. https://doi.org/10.1111/j.1467-8535.2005.00544.x

DOI:

10.1111/j.1467-8535.2005.00544.x

Document status and date:

Published: 25/07/2005

Document Version:

Peer reviewed version

Please check the document version of this publication:

- A submitted manuscript is the version of the article upon submission and before peer-review. There can be important differences between the submitted version and the official published version of record. People interested in the research are advised to contact the author for the final version of the publication, or visit the DOI to the publisher's website.

- The final author version and the galley proof are versions of the publication after peer review.

- The final published version features the final layout of the paper including the volume, issue and page numbers.

Link to publication

\section{General rights}

Copyright and moral rights for the publications made accessible in the public portal are retained by the authors and/or other copyright owners and it is a condition of accessing publications that users recognise and abide by the legal requirements associated with these rights.

- Users may download and print one copy of any publication from the public portal for the purpose of private study or research.

- You may not further distribute the material or use it for any profit-making activity or commercial gain

- You may freely distribute the URL identifying the publication in the public portal.

If the publication is distributed under the terms of Article 25fa of the Dutch Copyright Act, indicated by the "Taverne" license above, please follow below link for the End User Agreement:

https://www.ou.nl/taverne-agreement

Take down policy

If you believe that this document breaches copyright please contact us at:

pure-support@ou.nl

providing details and we will investigate your claim.

Downloaded from https://research.ou.nl/ on date: 26 Apr. 2023 


\title{
Applying reflection and moderation in an asynchronous computer-supported collaborative learning environment in campus-based higher education
}

\author{
Silvia Dewiyanti ${ }^{1}$, Saskia Brand-Gruwel ${ }^{2}$ \& Wim Jochems ${ }^{2}$ \\ ${ }^{1}$ University of the South Pacific, Distance \& Flexible Learning Support Centre, Suva, Fiji \\ Islands. \\ ${ }^{2}$ Educational Technology Expertise Center, Open University of the Netherlands
}

Working together while accomplishing a task is a characteristic of a powerful learning environment that aims at active knowledge construction. Studies have demonstrated that collaborative learning by using asynchronous communication tools can have advantages over collaboration in a face-to-face setting. However, it is questionable whether students are able and willing to learn collaboratively through these new kinds of learning environments. The present research investigates whether asynchronous collaborative learning is a feasible learning method for student teachers. In particular, this article explores issues of students' participation, interaction, and experience while using an asynchronous Computer-Supported Collaborative Learning (CSCL) environment to facilitate collaborative learning. Two studies that apply various instructional settings are presented. Findings show that students did not use CSCL environment effectively to facilitate their collaboration. A low participation rate, a limited interaction, and some negative experiences indicate that more studies in various topics in CSCL environment are needed.

British Journal of Educational Technology, 36, 673-676.

http://www.blackwell-synergy.com/doi/abs/10.1111/j.1467-8535.2005.00544.x

(c) 2005 Blackwell. 